- less than the rate of inflation after 1998 , when a full assessment would also be made of commitments from non-member states, and thus of the likely completion date.

Furthermore, there appears to have been agreement already on a new voting procedure in the CERN council that would give Germany greater power to veto future spending plans.

A new procedure would require all spending to be approved by countries contributing at least two-thirds of the budget; in practice, this means it could be blocked by Germany and one other major contributor (such as Britain), as such a combination provides more than one-third of the total budget.

German and British officials are confident that the chances of agreement are high. But the outcome remains dependent on France. One compromise being suggested on Monday was that, rather than accept the full demand for the host country premium, France could agree to make up the one per cent gap between the proposed budget increases after 1998 , and the real inflation rate.

If France rejects any such compromise, its action would cast significant doubts on its credentials as a supporter of high-level European science. Conversely, although the German pressure appears to have provoked some resentment (not only in Paris), observers say that Germany is sufficiently confident in its approach to be prepared to weather any storms it may have provoked.

Indeed, given that Germany is also the biggest contributor to CERN's budget, even after a recent temporary reduction because of the costs of reunification, there is a pragmatic acceptance that, as one official puts it, "he who pays the piper calls the tune".

David Dickson

\title{
Figures reveal Europe still falling behind US research
}

Paris. The European Commission has produced for the first time a single volume of science and technology indicators dedicated to describing research in the European Union (EU) and its place in the post-Cold-War world. In particular, the report - a brainchild of Antonio Ruberti, the outgoing research commissioner shows that the United States has "recovered" its technological lead over the past three years, while new Asian economies are now "catching-up".

At the same time, it reveals that Europe's reservoir of scientists and engineers is only about half that of the North American Free Trade Association. The report warns that this may decline further in comparison to North America and South-East Asia - and that, without a sustained economic recovery, Europe will increasingly have to select its priorities and slim its research organizations.

The 337-page volume was prepared in less than six months by the commission, in association with five science policy units (one in Maastricht, the Netherlands, one in Paris, and three in the United Kingdom). Luke Georghiou of the Programme of Policy Research in Engineering Science and Technology (PREST) at the University of Manchester describes it as the "most comprehensive" analysis of European science so far. This first report will be updated regularly within the EU's new socio-economic research programme.

In addition to flagging the overall distance that Europe trails behind both Japan and the United States, the report paints a bleak picture of European competitiveness in computing and electronics, illustrating how, despite EU programmes such as ESPRIT, the gap with both the United States and Japan is widening. Europe, however, remains strong in pharmaceuticals, aerospace and automobiles, and is holding its own in telecommunications.

The report confirms that the high growth of research budgets during the 1980 s in Europe has been replaced in the 1990 s with cutbacks because of the recession, and points out that these falls have been most marked in the public sector.

Another trend is a general reduction on research spending on energy and defence. At the same time, there has been an increase in research orientated towards socioeconomic objectives such as health and the environment.

The report also emphasizes the growing trend of globalization of research, with an increase in internationally coauthored papers, and in the number of overseas company laboratories.

Declan Butler

The European Report on Science and Technology Indicators 1994 (EUR 15897 EN) (ISSN 1018-5593).

\section{Nuclear industry seek US/Europe agreement on export controls}

London. The international nuclear fuel industry is putting pressure on the United States to break a deadlock in negotiations over a new Nuclear Cooperation Agreement with Euratom, the European nuclear agency, to succeed the current agreement, which expires at the end of 1995 .

The main sticking point is the United States' insistence on retaining 'prior consent rights' on nuclear material of US origin, in line with the Nuclear Non-Proliferation Act (NNPA) signed in 1978 by President Jimmy Carter.

As the US-Euratom Nuclear Cooperation Agreement, signed in 1958, pre-dates the NNPA, conflict with Europe has so far been avoided by an annual waiver issued by the US president. But Congress is unlikely to agree to a long-term waiver.

As a result, the United States has therefore offered Euratom terms similar to those in its bilateral agreement with Japan. This includes 'programmatic approval', which effectively means that use of nuclear material, equipment or technology of US origin has to be agreed by both parties before transfer occurs.

But this proposal has not been welcomed by the 12 member states of the EU. "The idea that the United States has a supervisory role is unacceptable to them," says Clark. In March this year the EU's Energy Commissioner, Abel Matutes, wrote to Warren Christopher, the US Secretary of State, saying that the United State's prior consent' requirements were unacceptable.

In explaining this decision, Matutes pointed out that "Western Europe and the USA are two equal partners who have attained a comparable leading position in the use of nuclear energy, and are equally strongly committed to non-proliferation."

The Uranium Institute (UI), which represents 80 companies in 18 countries - including uranium mining companies, electrical utilities, fuel processing and trading companies - says that failure to reach agreement would be a major setback for the whole nuclear industry.

The immediate consequences will be the interruption of nuclear exports from US companies to the European Union (EU). But
Gerald Clark, secretary general of the institute, says the knock-on effects could be even greater.

In particular, third countries would be prevented from transferring to the EU any nuclear material that is US-obligated, that is, any fuel that has been mined, enriched, fabricated or converted at some stage in its life in the United States. In addition, Clark warned last week, continued investment in nuclear power could be jeopardized by a lack of security in long-term contracts.

Failure to reach a new agreement could also threaten negotiations over extending the Nuclear Non-Proliferation Treaty (NPT), due to take place next year. The UI fears that such a failure might be interpreted by the rest of the world as a "complete breakdown" in nuclear cooperation between two major nuclear trading areas.

The nuclear industry, according to the Uranium Institute, would be happy to see an extension of the current system. "The fact is that the existing arrangements, although untidy, do work," says Clark.

Maggie Verrall 